\title{
Major and Minor Head Losses Analysis on The Piping System in Pondok Pesantren Tahfizhul Qur'an Ibnu Abbas Tarakan
}

\author{
Sudirman \\ Department of Mechanical Engineering \\ University of Borneo Tarakan \\ sudirman_dhuha@borneo.ac.id
}

\begin{abstract}
The head loss analysis in this study is focused on the existing piping system at the Ibnu Abbas Tarakan Tahfizhul Qur'an Islamic Boarding School, so that it is known that the flow losses that occur are both major losses and minor losses. The stages taken are; literature review by reviewing several previous studies then continued with data collection on the piping system in Ibnu Abbas Tarakan Islamic Boarding School. The discussion of head losses in the piping system is divided into four parts according to the existing branching of the pipe installation when the water comes out of the pump. Head losses in each section, namely; the first section (A) $0.21 \mathrm{~m}$, the second section (B) $0.47 \mathrm{~m}$, the third section (C) $0.3 \mathrm{~m}$. Whereas in the fourth section, the existing pipe installation is not supplied by water when the water flow from the pump is distributed simultaneously in the four existing pipe branches. The pump is unable to serve the existing pipe installation, if it is flowed simultaneously.
\end{abstract}

Keywords - head losses, major losses, minor losses, piping system

\section{INTRODUCTION}

Water piping systems are often found in everyday life, from households, schools, offices, hotels, and industries. Proper piping installation will reduce flow losses that occur in the piping system. The flow loss that occurs in the piping system is directly proportional to the energy loss that occurs. Head losses are the loss of mechanical energy in the mass of fluid. The unit head losses is a unit of length which is equivalent to one unit of energy required to move one unit of mass of fluid as high as one unit of length accordingly. Head losses are divided into two parts, namely major losses and minor losses, major losses are flow losses caused by friction between the fluid and a straight pipe wall which has a fixed cross-sectional area, minor losses are losses in fluid flow inside pipes caused by the cross-sectional area of the flow, entrance, fittings, and so on.

Head losses analysis in this study focused on the existing piping system at Ibnu Abbas Tarakan's Tahfizhul Qur'an Islamic Boarding School. Where the piping system in this boarding school serves five heads of families who build the boarding school and 78 students by using one source of drilled water which is raised using a water pump unit. The pump operating hours for daily activities at this Islamic boarding school are between 14 and 18 hours per day. So it is necessary to analyze the existing piping system in order to know the flow losses that occur. It is hoped that the results of this study can be followed by a proposal for a clean water piping system with lower flow losses so that it can reduce operational hours of water pump use. This will certainly reduce the operating costs of electricity.

Several studies related to flow loss analysis and piping systems were carried out by Ismet Eka Putra et al in 2017 [1] with the research title, "Analysis of Flow Loss (Head Losses) on PVC Pipe Bends". This study aims to determine the flow loss at $45^{\circ}$ and 90 aliran bends. Retrieval of data to measure flow loss in this study is to measure the difference in the height of the water in the manometer. The result of this research is that any bends will result in flow loss. The average flow loss at curves $45^{\circ}$ and $90^{\circ}$ is 0.003418 meters and 0.016093 meters, respectively, with the energy loss coefficient values of 0.24 and 1.13, respectively. The larger the turning angle will affect the flow loss, the bigger the angle the greater the flow loss.

Another research is research conducted by Aulia Windyandari, et al. In 2013 [2] with the title, "Design of KM Piping Systems. Nusantara (Piping System) ". The final result of this research is the piping system design on a ship, namely KM. Nusantara, by considering the piping system that is the most effective in its operation. Meanwhile, Sepfitrah and Yose Rizal [3] have studied pressure drop in piping systems using numerical methods in 
2013 with the research title, "Pressure Drop Analysis in Pipe Installation Flow Loss Testing Equipment Using CFD Fluent 6.0". This study aims to determine the magnitude of the influence of the geometry of the pipe components and the roughness of the pipe section on the pump performance and the resulting pressure drop, then perform a fluid flow simulation to determine the flow losses in the pipe. From the results of the study, it is known that the difference in the flow rate generated by the pump with the discharge stated in the pump specifications. This is due to the large amount of resistance that occurs along the pipe installation which causes the pump rotation to weaken.

Gaspar Y. K. Tuames et al, [4] conducted a study with the title, "Technical Planning of Clean Water Piping Networks with a Pumping System in Susulaku A Village, Insana District, North Central Timor Regency". The research was conducted in 2015 with the aim of planning a clean water piping network with a pump drainage system in Susulaku Village. The method used in calculating the population projection uses the Arithmetic Method, calculating the increase in the number of facilities, as well as calculating the water demand projection. Then perform hydraulic analysis on pumps and pipelines as well as matters to be considered in the operational and maintenance system.

Nasaruddin [5] conducted research on Major and Minor Losses Head of Distribution Pipe Network at Kupang State Polytechnic. In this study, it was observed that the piping system from the PDAM leading to the Padang State Polytechnic, the water flowing from the PDAM during 2018 the water flow was very small and rarely flowed. There is no problem if it is solved by improving the water distribution system to reduce losses. In this study, it was also stated that the distribution of water can flow normally if a piping installation is made and the estimated pump specifications are planned.

Based on the studies that have been mentioned above, this research has a correlation with what has been achieved in previous studies, namely the need for a proper piping system for specific uses in order to obtain a minimum flow loss value for a piping system. So that this research is needed in the conditions that have been described in the background section. Previous studies have become reference materials in determining analysis methods and planning the right piping system for the desired piping system requirements.

\section{Methods}

The research flow diagram is described in Figure 1 as follows:

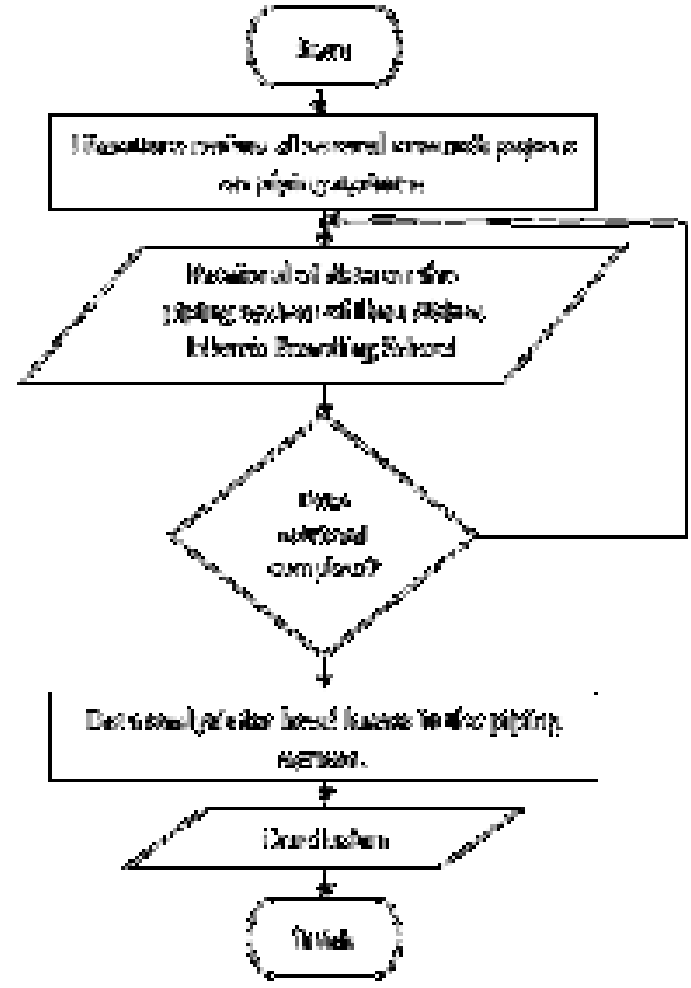

Fig. 1. Research Flow.

The research process was preceded by reviewing several previous studies to determine the extent to which previous researchers had discussed this topic. This is to facilitate the analysis process, where these data become comparative data and reference data to facilitate the analysis that is being carried out in this study.

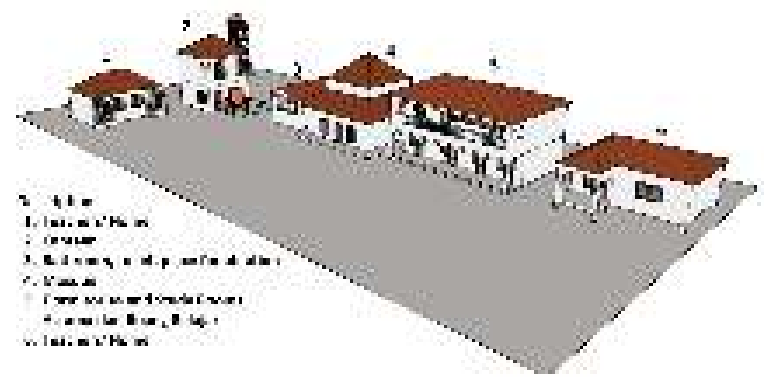

Fig. 2. Building Plan at Ibnu Abbas Tarakan Islamic Boarding School.

The next step is to take the existing piping system data at the Ibnu Abbas Tarakan Islamic Boarding School, the results of data retrieval are shown in Figure 2 and Figure 3. The branching of the pipe installation from the pump and the pump specifications used are shown in Figure 4. The data is analyzed to determine the amount of head losses. which happened to the piping system of the Ibnu Abbas Tarakan Islamic Boarding School. The results of the analysis are the conclusions of this research which can then be a recommendation if a redesign of the piping system is needed at Ibnu 


\section{BEST}

Journal of Applied Electrical \& Science Technology - University of PGRI Adi Buana Surabaya

Abbas Tarakan's Tahfizul Qur'an Islamic Boarding School.

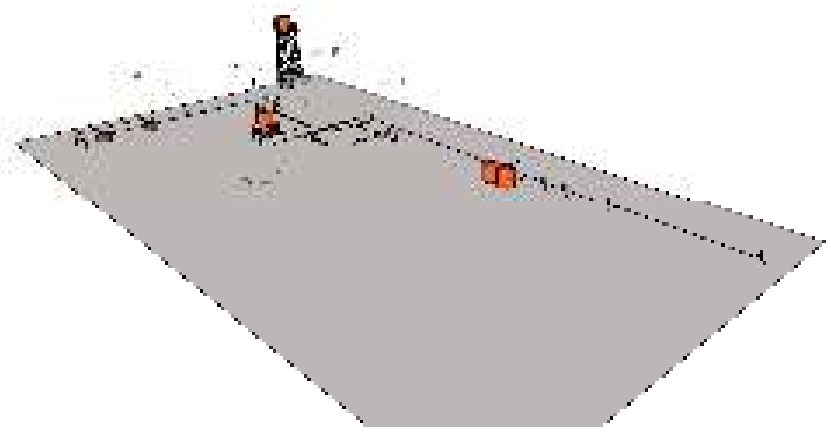

Fig. 3. Plan for the Distribution of Water from Pumps to A: Building 1, B: Water reservoir 3, C: Building 5 and 6, D: Water reservoir 3 to the bathroom, toilet, and place of ablution, E: Building 2.

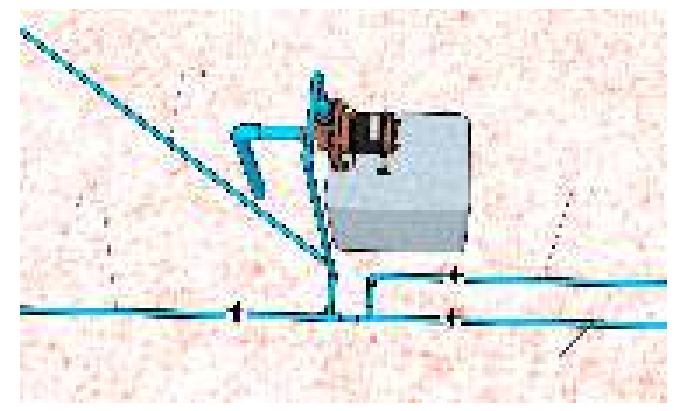

Fig. 4. Water Supply from Pumps to Parts A, B, $\mathrm{C}$ and $\mathrm{E}$.

Pump specifications used are:

$\begin{array}{ll}\text { Brand } & : \text { Sanyo P-WH 236C } \\ \text { Output power } & : 200 \mathrm{~W} \\ \text { Suction power } & : \text { Max. } 9 \mathrm{~m} \\ \text { Flow height } & : \text { Max. } 30 \mathrm{~m} \\ \text { Maximum capacity } & : 451 / \mathrm{min} \\ \text { Minimum capacity } & : 291 / \mathrm{min}\end{array}$

\section{RESULT AND DISCUSSION}

Major losses occur due to fluid flow friction along the pipe. The amount of major losses is influenced by pipe length $(L)$, pipe diameter $(D)$, fluid flow velocity $(V)$, fluid viscosity $(\mu)$, and pipe material. Major losses are calculated by the following equation:

For laminar flow

$$
h_{l_{\text {mayor }}}=\left(\frac{64}{R e}\right) \frac{L}{D} \frac{\bar{V}^{2}}{2}
$$

For turbulent flow

$$
h_{l_{\text {mayor }}}=f \frac{L}{D} \frac{\bar{V}^{2}}{2}
$$

Where $f=$ friction factor obtained from experimental data which is plotted in the Moody Diagram. In the Moody Diagram, $f$ is determined based on $R e$ and the relative surface roughness, $\varepsilon / D$ which is determined based on the diameter of the pipe. The friction factor for laminar flow is $64 / R e$, this is in accordance with the experimental results that for laminar flow, $f$ only depends on $R e$, while $\varepsilon / D$ has no effect. Table 1 shows the Equivalent Roughness for several types of pipes. The transition from laminar to turbulent causes the velocity gradient near the wall to become larger.

TABLE I. EQUIVALENT ROUGHNESS FOR SEVERAL

\begin{tabular}{|c|c|c|}
\hline \multirow[b]{2}{*}{ Yyog } & \multicolumn{2}{|c|}{ 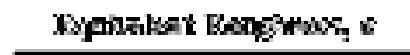 } \\
\hline & xot & boukstifery \\
\hline Hises $=40$. & 1051-2103 & (2) $18-45$ \\
\hline Givaris & $30 \mathrm{j} i-\beta M$ & $0,3 \Rightarrow$ \\
\hline "sod 2 tw:: & AESt: SWDS & $218-75$ \\
\hline Tane Inax & ances: & ats \\
\hline 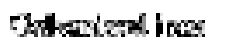 & Thetis & Brats \\
\hline 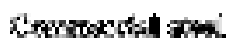 & & \\
\hline 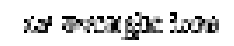 & thesist3 & aids \\
\hline 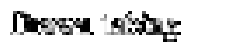 & aratis & 6. \\
\hline 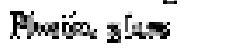 & 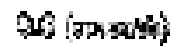 & 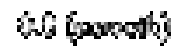 \\
\hline
\end{tabular}
TYPES OF PIPE (MUNSON ET AL., 2009)

Minor losses occur due to changes in flow direction, changes in flow cross-section and changes in friction due to fittings (bends, branches, valves, etc.). The basic procedure for determining minor losses is the equivalent length method and using the Losses Coefficient. In this study, the loss coefficient method was used. Each fitting has a loss coefficient, $\mathrm{K}$, which when multiplied by the pressure velocity term results in the amount of losses. as in equation 3 below,

$$
h_{l_{\text {minor }}}=K \frac{\bar{V}^{2}}{2 g}
$$




\section{A. Calculating major and minor losses in the} piping installation of Ibnu Abbas Tarakan Islamic boarding school

The calculation is carried out when all the valves are open and the pump supplies water to part A, part B, part C, and part E simultaneously (see Figure 4).

- Losses in part A after water exits the pump

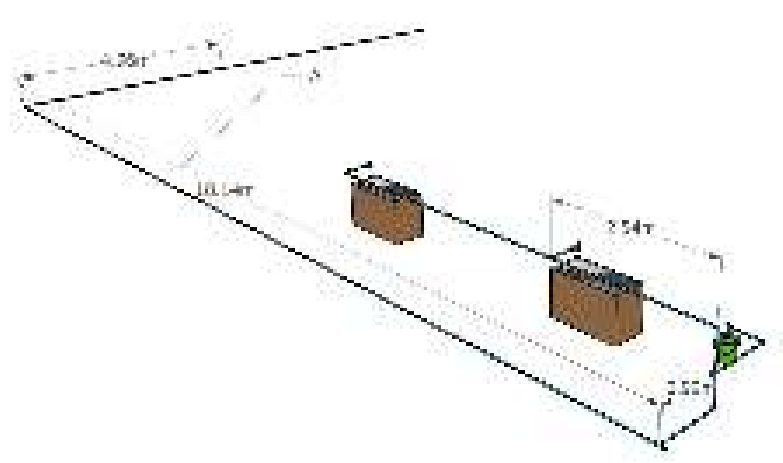

Fig. 5. Pipe Installation in Part A After Water Exits the Pump to the Building 1.

The following is the pipe and water flow data in part A:

Pipe length $\left(L_{A}\right)=26,63 \mathrm{~m}$

Pipe diameter $\left(D_{A}\right)=17,6 \mathrm{~mm}=0,0176 \mathrm{~m}$

Flow rate $\left(Q_{A}\right)=1$ liter $/$ minute $=2 \times 10^{-5} \mathrm{~m}^{3} / \mathrm{s}$

Kinematic viscosity of water $(v)=1 \times 10^{-6} \mathrm{~m}^{2} / \mathrm{s}$

Pipe roughness $(\varepsilon)=$ smooth pipe

Calculation of major losses in part A:

Cross-sectional area $\left(A_{A}\right)=\frac{\pi D^{2}}{4}=$ $2,4 \times 10^{-4} \mathrm{~m}^{2}$

Flow velocity $\left(V_{A}\right)=\frac{Q_{A}}{A_{A}}=\frac{2 \times 10^{-5}}{2,4 \times 10^{-4}}=$ $0,083 \mathrm{~m} / \mathrm{s}$

Reynold number $(R e)=\left(\frac{V_{A} D_{A}}{v}\right)=1.460,8$ laminar flow 0,04

friction factor $(f)$ laminar flow $=\frac{64}{R e}=\frac{64}{1.460,8}=$

So that the major losses are $\left(h_{l}\right)=f \frac{L}{D} \frac{\bar{V}^{2}}{2}==$ $0,21 \mathrm{~m}$

Calculation of minor losses in part A: 1,2

The number of elbows $90^{\circ}=4, k_{1}=4 \times 0,3=$

Number of tees $=2, k_{2}=2 \times 0,2=0,4$ 0,05

The number of ball valves $=1, k_{3}=1 \times 0,05=$

$$
\begin{gathered}
h_{l_{\text {minor }}}=(1,2+ \\
=0,4+0,05) \frac{\overline{0,083}^{2}}{2 \times 9,81} \\
=5,8 \times 10^{-4} \mathrm{~m}
\end{gathered}
$$

- Losses in part B after water exits the pump

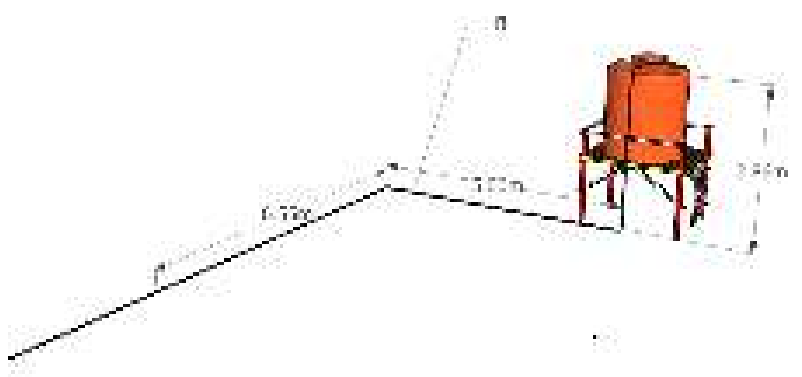

Fig. 6. Pipe Installation in Part B After the Water Exits the Pump to the Building Tandon 3.

The following is the pipe and water flow data in part B:

Pipe length $\left(L_{B}\right)=14,41 \mathrm{~m}$

Pipe diameter $\left(D_{B}\right)=21,4 \mathrm{~mm}=0,0214 \mathrm{~m}$

Flow rate $\left(Q_{B}\right)=4$ liter $/$ menit $=7 \times 10^{-5} \mathrm{~m}^{3} / \mathrm{s}$

Kinematic viscosity of water $(v)=1 \times 10^{-6} \mathrm{~m}^{2} / \mathrm{s}$

Pipe roughness $(\varepsilon)=$ smooth pipe

Calculation of major losses in part $\mathrm{B}$ :

Cross-sectional area $\left(A_{B}\right)=\frac{\pi D^{2}}{4}=$ $3,6 \times 10^{-4} \mathrm{~m}^{2}$

Flow velocity $\left(V_{B}\right)=\frac{Q_{B}}{A_{B}}=\frac{7 \times 10^{-5}}{3,6 \times 10^{-4}}=0,19 \mathrm{~m} /$ $S$

Reynold number $(R e)=\left(\frac{V_{B} D_{B}}{v}\right)=4.066$ laminar flow

friction factor $(f)$ flow transition from Moody's diagram $=0.039$

So that the major losses are $\left(h_{l}\right)=f \frac{L}{D} \frac{\bar{V}^{2}}{2}=$ $0,47 \mathrm{~m}$

Calculation of minor losses in part B: 1,2

The number of elbows $90^{\circ}=4, k_{l}=4 \times 0,3=$

$$
h_{l_{\text {minor }}}=(1,2) \frac{\overline{0,19}^{2}}{2 \times 9,81}=2,2 \times 10^{-3} \mathrm{~m}
$$

- Losses in section $\mathrm{C}$ after water exits the pump

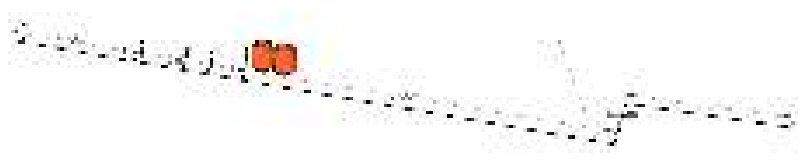

Fig. 7. Pipe Installation in Section $C$ After Water Exits the Pump Towards Building 5 and Building 6.

The following is the pipe and water flow data in part C:

Pipe length $\left(L_{C}\right)=57,47 \mathrm{~m}$ 
Pipe diameter $\left(D_{C}\right)=21,4 \mathrm{~mm}=0,0214 \mathrm{~m}$

Flow rate $\left(Q_{C}\right)=2$ liter/menit $=3 \times 10^{-5} \mathrm{~m}^{3} / \mathrm{s}$

Kinematic viscosity of water $(v)=1 \times 10^{-6} \mathrm{~m}^{2} / \mathrm{s}$

Pipe roughness $(\varepsilon)=$ smooth pipe

Calculation of major losses in part C:

Cross-sectional area $\left(A_{C}\right)=\frac{\pi D^{2}}{4}=$ 3,6 $\times 10^{-4} \mathrm{~m}^{2}$

Flow velocity $\left(V_{C}\right)=\frac{Q_{C}}{A_{C}}=\frac{3 \times 10^{-5}}{3,6 \times 10^{-4}}=$ $0,083 \mathrm{~m} / \mathrm{s}$

Reynold number

$(R e)=\left(\frac{V_{C} D_{C}}{v}\right)=$

1.776,2 laminar flow

friction factor $(f)$ flow transition from Moody's diagram $=0.036$

$0,3 \mathrm{~m}$

So that the major losses are $\left(h_{l}\right)=f \frac{L}{D} \frac{\bar{V}^{2}}{2}=$

Calculation of minor losses in part $\mathrm{C}$ : 1,5

The number of elbows $90^{\circ}=5, k_{1}=5 \times 0,3=$

Number of tees $=4, k_{2}=4 \times 0,2=0,8$

The number of ball valves $=1, k_{3}=1 \times 0,05=$ 0,05

$$
\begin{aligned}
h_{l_{\text {minor }}}=(1,5+ & 0,8+0,05) \frac{\overline{0,083}^{2}}{2 \times 9,81} \\
& =8,3 \times 10^{-4} \mathrm{~m}
\end{aligned}
$$

- Losses in section E after water exits the pump

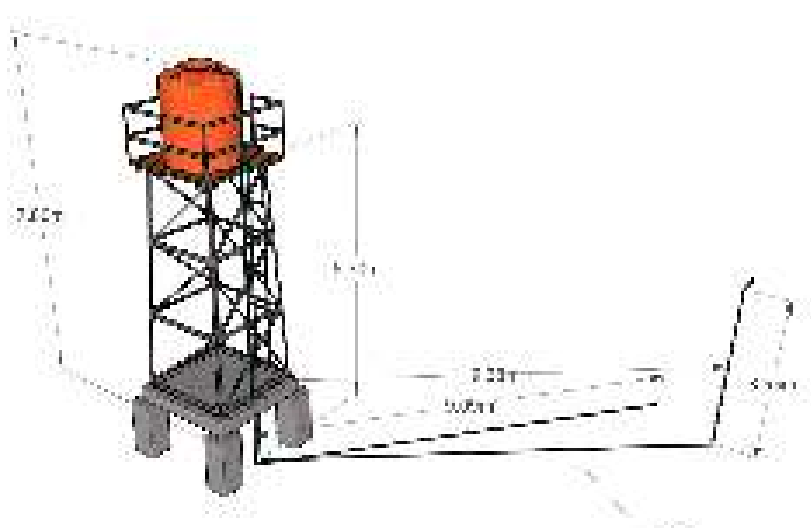

Fig. 8. Pipe Installation Part E After Water Exits the Pump to the Tandon and Buildings 2. .

In this section head losses are not calculated because in the simulation carried out by draining water from the pump and opening the valve at all branches in Figure 4, the water does not flow to section E. In Table II, the calculation results for major and minor losses for each section are shown.
TABLE II. EQUIVALENT ROUGHNESS FOR SEVERAL TYPES OF PIPE (MUNSON ET AL., 2009)

\begin{tabular}{|c|c|c|c|}
\hline Section & Major & Minor & Total \\
\hline $\mathrm{A}$ & $0,21 \mathrm{~m}$ & $5,8 \times 10^{-4} \mathrm{~m}$ & $\begin{array}{c}0,21058 \\
m\end{array}$ \\
\hline $\mathrm{B}$ & $0,47 \mathrm{~m}$ & $2,2 \times 10^{-3} \mathrm{~m}$ & $0,4722 \mathrm{~m}$ \\
\hline $\mathrm{C}$ & $0,3 \mathrm{~m}$ & $8,3 \times 10^{-4} \mathrm{~m}$ & $\begin{array}{c}0,30083 \\
m\end{array}$ \\
\hline Total & $0,98 \mathrm{~m}$ & $0,00361 \mathrm{~m}$ & $\begin{array}{c}0,98361 \\
m\end{array}$ \\
\hline
\end{tabular}

\section{B. Calculating Pump Head}

The total pump head is calculated using the following equation 4 :

$$
\begin{aligned}
& H=h_{a}+\Delta h_{p}+h_{l}+\frac{v_{d}^{2}}{2 g} \\
& h_{a}=(7,8+9+2,9)=19,7 \\
& h_{l}=1 \mathrm{~m} \\
& H=h_{a}+\Delta h_{p}+h_{l}+\frac{v_{d}^{2}}{2 g}=20,7 \mathrm{~m}
\end{aligned}
$$

In this research, the pump specification used is a pump with a maximum head of $39 \mathrm{~m}$, so that theoretically the pump is still able to serve the needs of pipe installation at the Islamic boarding school tahfizhul quran ibnu abbas tarakan. However, in its application, the pump is not able to serve the existing pipe installation with no water flowing in section E. This is due to the decreased efficiency of the pump due to the supply voltage which does not match the pump operational voltage, which is 220 volts. This has been researched by Nazaruddin et al in 2018 [6], that with the variation in electric voltage, it is known that the flow rate is decreasing. The variation of the voltage that is given from 220 volts to 100 volts gives a change to the decreasing flow rate.

\section{CONCLUSIONS}

Based on the results of the discussion above, the following conclusions are obtained:

- Major and minor losses in part A are $0.21 \mathrm{~m}$ and $0.00058 \mathrm{~m}$, respectively

- Major and minor losses in section B are $0.47 \mathrm{~m}$ and $0.0022 \mathrm{~m}$, respectively

- Major and minor losses in section D are $0.3 \mathrm{~m}$ and $0.00083 \mathrm{~m}$, respectively

- 4.In part E, the losses that occur cannot be calculated because when the simulation is carried out by opening all the branch valves of the pump, the water does not flow through section $\mathrm{E}$ 
- Based on the conclusion of point 4 , the pump cannot serve the needs of the pipe installation if all drains are opened simultaneously.

- The specifications of the pump installed should be able to drain water in all parts according to the existing pipe installation based on the calculation of the pump head.

- The pump cannot serve the installation needs, which can be caused by decreased pump performance

\section{REFERENCES}

[1] Putra, I.E., Sulaiman, Galsha, Ari, "Analisa Rugi Aliran (Head Losses) pada Belokan Pipa PVC" Seminar Nasional PIMIMD Padang, pp. 34-39, July 2017.

[2] Widyandari, Aulia., Janah, Jati Iffa., "Perancangan Sistem Perpipaan KM.
Nusantara (Piping System)" Kapal, vol. 10 No. 3, October 2013, pp.154-163.

[3] Sepfitrah., Rizal, Yose., " Analisa Pressure Drop Pada Instalasi Pipa Alat Uji Rugi-Rugi Aliran Mengunakan CFD Fluent 6.0" Jurnal Aptek Vol. 5 No. 1, pp. 45-56, January 2013.

[4] Tuames, G.Y.K., Bunganaen, Wilhelmus., Utomo, Sudiyo "Perencanaan Teknis Jaringan Perpipaan Air Bersih Dengan Sistem Pengaliran Pompa di Desa Susulaku A Kecamatan Insana Kabupaten Timor Tengah Utara” Jurnal Teknik Sipil Vol. IV, No. 1, pp. 1-15, April 2015.

[5] Nasaruddin., "Mayor dan Minor Losses Head Jaringan Pipa Penyalur Pada Politeknik Negeri Kupang” JTM - Jurnal Teknik Mesin, Vol. 1 No. 2, pp. 86-94, December 2018.

[6] Nazaruddin., Yuliani., "Pengaruh Tegangan Listrik Terhadap Performa Pompa" JTM Jurnal Saintek STT, Vol. 6 No. 1, pp. 15-22, 2018. 